Journal of Social Sciences (COES\&RJ-JSS)

ISSN (E): 2305-9249 ISSN (P): 2305-9494

Publisher: Centre of Excellence for Scientific \& Research Journalism, COES\&RJ LLC

Online Publication Date: $1^{\text {st }}$ October 2017

Online Issue: Volume 6, Number 4, October 2017

https://doi.org/10.25255/jss.2017.6.4.902.911

\title{
The Development of Lesson-Study-Based Thematic Learning in the Implementation of Curriculum 2013 Oriented on Regional Diversity for Grade 3 in Malang
}

\author{
Sri Harmini, Endang Setyo Winarni, Sihkabuden \\ Elementary School Teacher Education, Faculty of Education, \\ Universitas Negeri Malang, East Java Indonesia
}

\begin{abstract}
:
This research is aimed at training the teachers through lesson study in cooperation with other teachers for discussion on: (1) Integrated Thematic Lesson Plan (LP) based on curriculum 2013 for grade 3 of elementary school, (2) implementation of integrated thematic lessons according to curriculum 2013 for grade 3 of elementary school, and (3) making the Integrated Thematic learning tool in the form of LP according to curriculum 2013 and VCD of learning for grade 3 of elementary school. The data were collected from 12 teachers of grade 3 of the elementary schools in Malang. From the data, then analyzed descriptively by: (a) checking the validity of data, (b) identifying and classifying data and (c) data analysis done by calculating the percentage and determining the results of the discussion. Research in the phase I used the descriptive method, qualitative and the data were analyzed by changing percentage. The results of the phase I are aimed at: (a) developing the Integrated Thematic Lesson Plan (LP) based on curriculum 2013 through lesson study, (b) imroving or revising the LP according to curriculum 2013 through lesson study (c) implementing learning process through LP test according to curriculum 2013 which has been enhanced through lesson study, (d) making the VCD of learning implementation using LP according to curriculum 2013 which has been revised. The research method is in the form of training and developing prototype. Expected outcomes include: (a) learning tools in the form of Integrated Thematic LP based on the lessonstudy-based learning of curriculum 2013 and (b) Thematic Integrated VCD learning based on the lesson-study-based learning of curriculum 2013.
\end{abstract}

Keywords:

Thematic Learning, Lesson Study, Curriculum 2013, Elementary School

\section{Citation:}

Harmini, Sri; Winarni, Endang Setyo; Sihkabuden (2017); Implementation of Curriculum 2013 Oriented on Regional Diversity for Grade 3 in Malang; Journal of Social Sciences (COES\&RJ-JSS), Vol.6, No.4, pp:902-911; https://doi.org/10.25255/jss.2017.6.4.902.911. 


\section{Introduction}

The government always strives to improve the quality of teachers to be professional teachers, professional teachers must have 4 competencies of academic, professional, personality and social. In carrying out its professional duties the teachers are obliged to plan learning, implementing quality learning as well as assessing and evaluating learning as stated in RI Law No. 14 Year 2005 about Teacher and Lecturer (Ibrohim, 2012).

In order to create Lesson Plan (LP) and learning implementationmore qualified, this reseach is conducted through lesson study. After the integrated thematic LP based on curriculum 2013 has been made, then this research conducted peer teaching to carry out the learning and get suggestions from the teachers. Furthermore, LP is validated by expert/lecturer of integrated thematic learning or integrated learning to be tested in the real teaching in grade 3 of elementary students.

The LP was made by mentioning (a) identity, basic competence, indicator, and learning objectives (b) the development and organization of materials (c) planning of learning scenarios, (d) classroom management design and (e) planning of procedures, types and assessment preparations. The teachers of grade 3 becomes the subjects of this research, data and data sources in the form of design and learing implementation description. Learning flow in its implementation involves: (a) initial activity involves giving perceptions, material information / themes that being learned and information on learning objectives to be achieved; (b) core activities include activities that focus on students, scientific approach and perception equation on the material that being studied and (c) the final activity involves making the conclusion, the student complete the questions as the evaluation of them in conveying the reflection and getting the questions for homework.

Real teaching is conducted as experiment test, then the results were discussed by the teachers as lesson study participants to improve it and implement the lesson that will be made in the form of VCD. Based on the description above, it is necessary to conduct a research entitled: "The Development Of Lesson-Study-Based Thematic Learning in the Implementation of Curriculum 2013 Oriented on Regional Diversityfor Grade 3 in Malang".\#

\section{Methods}

Based on the nature and types of research problems and objectives that this research intends to achieve, it is designed to be implemented within two years.

\section{Research of the First Year}

The problems of the researcher that will be solved in the first phase are: (a) How to describe the data according to curriculum 2013 that must be observed in the form LP in grade 3 of elementary school, (b) How to describe the data according to curriculum 2013 to be improved in the form of LP in grade 3 of elementary school, (c) How to test the learning implementation according to the thematic pictured in the LP that has been observed and completed through the lesson study, (d) How is the description of the test result that makes the VCD implementation of learning fits the RPP that have been refined through lesson study.

Therefore the procedures to be taken in solving the problem, as follows. 


\section{Research Design}

The phase I research uses descriptive research design. This research aims to describe in a systematic, detailed and accurate manner on (a) How to describe the results of discussion LP according to curriculum 2013 that must be observed in the form of Thematic Lesson Plan (LP) in Grade 3 of elementary school, (b) How to describe the data of LP discussion result according to curriculum 2013 that should be improved in the form of Lesson Plan for grade 3 of elementary school, (c) How to test the implementation of learning according to the thematic LP pictured in grade 3 of elementary school that has been observed and completed through lesson study, (d) How to describe the results of the experiment test which makes VCD implementation of learning according to the LP that has been improved through lesson study. Therefore, two ways are defined, namely survey and indepth interview with observation and documentation. Both of these are used as inputs for the development of an integrated thematic learning model based on lesson-study-based curriculum 2013 oriented on regional diversity (geographical characteristics) in grade 3 of elementary students in Malang.

\section{Research Variable}

The research variables that will be studied in the phase I of this research are the learning profile that includes (a) How to describe the discussion result data according to curriculum 2013 which must be observed in the form of Thematic LP in Grade 3 of elementary school, (b) How is the data results of the discussion according to curriculum 2013 that should be improved in the form of Lesson Plan (LP) in 3rd grade, (c) How to test the implementation of learning with integrated thematic LP according to curriculum 2013 in grade 3 of elementary schoool that has been observed and completed through lesson study,(d ) How to describe the results of experiment tests that makes the VCD of learning implementation according to the LP that has been improved through the lesson study. Therefore, two ways are defined, namely survey and in-depth interview with observation and documentation. Both of these are beneficial as inputs for the development of thematic learning models based on lesson study oriented on regional diversity (geographical characteristics) in grade 3 of elementary students in Malang.

\section{Population and Sample}

The population of this research are teachers who teach in schools located in Malang consisting of (a) the downtown, there are Klojen and Lowokwaru districts, (b) countryside, there are Blimbing sub-district and Sukun sub-district, (c) Village, there are Kedungkandang sub-district (suburb). The sample of each sub-district was selected 2 elementary schools, but specially the suburb of Malang was selected 4 elementary schools, so the total is $(2 \times 4)+4=12$ elementary schools.

\section{Research Instrument}

The instruments used in this research are questionnaires and interview guidelines. There are several steps taken in preparing a questionnaire. First, to describe the data of the discussion results according to curriculum 2013 which must be observed in the form of Thematic Lesson Plan (LP) in grade 3 of elementary school, (b) How to describe the data according to curriculum 2013 that must be improved in the form of Lesson Plan (LP) in the grade 3, (c) How to test learning implementation according to the thematic LP picture in Grade 3 of elementary school that has been observed and completed through the lesson study, (d) How is the description of the test results that make the VCD implementation of 
learning is suitable with the LP that was already improved through lesson study. As a result, it followed by two ways: survey and in-depth interview. Both of these are used as inputs for the development of thematic learning models through a lesson study with the orientation of regional diversity (geographical characteristics) for grade 3 of elementary school in Malang. The variable is translated into sub-variable. First, compiling the questions based on the items that always made. Second, examining the question items in terms of substance and technical administration. Third, making improvements to the instrument. Interviews used in this research were structured interviews. This interview contains the main questions and asks open answers from the respondents for improvement.

\section{Data Collection}

Experimental field assessment data is conducted by using questionnaires and interviews about the acceptance of the package. This questionnaire contains inputs of usability, dependability and accuracy. Interviews provide feedback on improvements to the training packages, the improvement of lesson-study-based thematic learning modules with the orientation of regional diversity (geographic characteristics) for the Grade 3 of elementary school in Malang. This research is also qualitative research as stated by Ulfatin (2012) that in qualitative research the researcher acts as a planner in designing the research, implementing the data collecting, analyzing the collected data and finally as reporter about the research result. Further experimental data will be collected by using questionnaires, interviews, observation and inventory.

\section{Data Analysis Technique}

Data analysis technique used in this research is descriptive analysis. The teacher's early knowledge about lesson study is stated by qualification as based on the percentage of answers (quantitative research). LP that has been discussed through lesson study is interpreted (qualitative research) and consulted to get feedbacks and suggestions from experts (lecturer of thematic learning). Comments and suggestions are used as a basis for improving the LP to be tested in real teaching. Observation sheets used by observer to observe the implementation of learning in terms of LP that has been developed (already revised) and student learning activities.

\section{Research of Second Year}

The research in the second year agreed with curriculum2013: (a) disseminating the integrated thematic LP and VCD of the research results in the first phase that resulted from the lesson study with the orientation of regional diversity (geographical characteristics) for grade 3 of elementary school in Malang on a large scale, b) improving the integrated thematic LP in teaching according to curriculum 2013 through a broader scale; (c) performing peer teaching from the LP according to the curriculum 2013 that has been improved through lesson study in a broader scale; (d) validating the LP according to curriculum 2013 that has been revised through lesson study to the validator (lecturer of integrated thematic teaching) and subsequently, LP validation results are tested on the students in real teaching which is then done through lesson study reflection and (e) creating integered thematic VCD learning to LP according to curriculum 2013 that has been revised through lesson study on a broader scale. 
Therefore, the procedures that will be carried out to solve the problem as follows:

\section{Research Design}

The research and development design used in this research, in the form of experimental study, to know the influence of using training package of intergrated learning model development through the lesson study with the orientation of regional diversity (geographical characteristics) for grade 3 of elementary school according to curriculum 2013 in Malang. The training package includes : (a) disseminating the integrated thematic LP and VCD of integrated learning results at the first phase resulting from the lesson study with the orientation of regional diversity (geographical characteristics) for the Grade 3 of elementary school in Malang in broader scale; (b) improving the integrated thematic lesson plan (LP) according to curriculum 2013 through lesson study on a broader scale, (c) performing peer teaching from the LP based on curriculum 2013 that has been revised through lesson study in a broader scale; (d) validating LP according to curriculum 2013 that has been revised through lesson study to the validator (lecturer of intergrated thematic learning) and subsequently, LP validation results are tested on the students in real teaching, which then reflected through lesson study and (e) creating integered thematic VCD learning and LP according to curriculum 2013 that has been revised through the lesson study in a broader scale. To make this happen, 2 ways like survey and in-depth interview were conducted to receive feedbacks and suggestions for the development of integrated thematic learning through lesson study.

\section{Research Subjects}

This research involves expert subjects and subjects of integrated thematic teaching objectives (lecturer of integrated thematic teaching). The target subjects were elementary school teachers in grade 3 from 5 sub-districts in Malang with 2 urban areas, 2 half-towns and half villages and 1 village area (suburb), the total number of subjects targeted by this research were 20 people from 20 elementary schools in Malang.

\section{Research Steps}

Based on the results of the research in Phase I, the research of Phase II was conducted with the following steps: (1) compiling learning materials, (2) validating by an integrated thematic learning expert in accordance with the 2013 curriculum; (3) revising training materials based on validation results from the validators, (4) conducting experiments on subjects of research objectives, and further (5) revising and rewroting the training materials as the development of integrated thematic learning model according to curriculum 2013 through lesson study with orientation of regional diversity (geographical characteristics) for grade 3 of elementary school in Malang.

\section{Instruments of data collection}

The data collection instruments used in this study are questionnaires and interviews. Except, the assessment of expert tests and field trials is also used to determine the acceptability of training materials, meanwhile improvement inputs for training materials for the development of thematic learning models through lesson study were also collected for improvement.

\section{Data Analysis Technique}

Data analysis technique used in this research is descriptive analysis. This research is a quantitative research, because the teachers' early knowledge about lesson study is stated 
by qualification according to percentage of teachers' answers. This research is also a qualitative research, because LP that has been discussed through lesson study is interpreted and consulted to get feedbackss and suggestions from experts (lecturer of thematic teaching). The feedbacks and suggestions are used as a basis for improving LP to be tested in real teaching. Observation sheets used by the observer to observe the implementation of learning considered by the LP that has been developed (already revised) and student learning activities.

\section{Research Flow}

Pre research includes:
a. Survey
b. Observation
c. Questionnaire
d. Interview
e. Documentation
f. Trial

$\downarrow$

Research includes:

a. Introducing lesson study to the teachers

b. Developing lesson-study-based lesson plan (LP)

c. Performing Peer teaching using LP that has been revised and improved through lesson study

d. Doing Real teaching (experimental) using LP that has been revised and improved through lesson study

e. Making VCD of learning process that impelements the LP that has been revised and improved through lesson study
Report of Research Results includes:
a. Data Analysis (quantitative and qualitative)
b. Formulation (discussion) of research findings
c. Packaging models and VCD learning

\section{RESULTS}

The results of this research are presented on: (1) results of problem solving which contain knowledge of Lesson study, by teachers and (2) implementation of learning to reach the determined goal, the activities which have been done in this research as follows: (1) 
preparing questionnaire and lesson study paper for the teacher training of grade 3 elementary school, (2) distributing the questionnaires about lesson study knowledge to elementary school teachers as respondents, (3) analyzing the questionnaire results, (4) conducting lesson study for elementary school teachers 3, (5) drafting and revising lesson plan (LP) through lesson study, (6) carrying out trials of LP that has been revised through Peer Teaching, (7) reflecting on test through lesson study, (8) validating LP to the experts, that is an integrated / thematic teaching lecturer (Dra Sri Sugiharti, M.Pd), (9) through the real teaching experiments on elementary school students from using LP that has been revised, (10) reflecting the results of the learning implementation from LP that has been implemented in Real Teaching on elementary school students by making VCD.

The results of problem solving which contain the knowledge of Lesson Study by teachers can be shown in the following table (Table 5.1)

\begin{tabular}{cccc}
\hline Number & $\begin{array}{c}\text { Correct } \\
\text { Answer }\end{array}$ & Frequency & $\%$ \\
\hline 1. & $\mathrm{~b}$ & 2 & 10 \\
2. & $\mathrm{a}$ & 3 & 15 \\
3. & $\mathrm{c}$ & 0 & 0 \\
4. & $\mathrm{~b}$ & 4 & 20 \\
5. & $\mathrm{c}$ & 8 & 40 \\
6. & $\mathrm{a}$ & 1 & 5 \\
7. & $\mathrm{c}$ & 1 & 5 \\
8. & $\mathrm{~b}$ & 3 & 15 \\
9. & $\mathrm{~d}$ & 3 & 15 \\
10. & $\mathrm{c}$ & 4 & 10 \\
11. & $\mathrm{c}$ & 2 & 20 \\
12. & $\mathrm{c}$ & 7 & 10 \\
13. & $\mathrm{~d}$ & 2 & 35 \\
14. & $\mathrm{c}$ & 3 & 10 \\
15. & $\mathrm{~d}$ & & 15 \\
\hline
\end{tabular}

By studying the table in column 5, in fact that almost $100 \%$ of teachers do not understand lesson study, so teachers training needs to be conducted.

Observation Results of experiments from elementary school teachers as the participants of Lesson Study of thematic learning implementation by doing peer teaching and after training

Impression: (1) get plenty of input and experience for improving the LP, (2) it is very fun, because it is performed in small groups, so the insight increases, (3) get lots of input from other participants to improve the LP, (4) can see sample model of teachers in delivering the lessons well.

Message: (1) pay more attention to the duration, (2) attention to students who is not evenly distributed (3) use of less standard language, (4) video presentation focuses on the material to be taught, (5) mobilization / movement of teachers is not only in front of the class.\#

\section{Lesson Plan (LP) that has been validated through Lesson Study by Validator}


Theme : development of animals and plants

Sub-theme : Animal breeding and cycling

Page number is unavaiable (it should be written)

B. Learning objectives No.1-9 (look at typing)

Learning Objectives should be operational verbs, there are elements of A, B, C, D

$\mathrm{A}=$ audience (student)

$\mathrm{B}=$ behavior (expected behaviors raise in the students)

$\mathrm{C}=$ measurable condition

$\mathrm{D}=$ degree (level of student achievement / skill)

Learning Objective no 4, no 5 (by identifying what example?).

D. Approaches, Models, and Methods

Methods: lecturing, question and answer, observation, assignment, discussion (note the correct order, according to the sequence of learning activities)

E. Learning process

Initial activity add no 6 for teachers deliver the learning objectives

Core activity no 2 and 3 (students discuss in group)

no 8 (students present the result of group discussion)

no 9 (other group perceives or add ideas)

no 10 dan no 11 (the correct one is first principle uses capital letter)

Close activity add no 4 (reflection assessment), and no 5 (moral value)

Media : learning Video (source of animal cycles of butterflies, frogs, and

cockroaches)

For more details, it can be made on manila paper

Garuda symbol source and first Sila

Learning sources:

1. Curriculum 2013

2. Teacher's hematic books 2012 (write the year and the writer)

3. Students' thematic books 2012 (write the year and the writer)

Appendix (write according to systematic material)

Appendix 1 material summary of Bahasa Indonesia

Appendix 2 material summary of Mathematics

Appendix 3 material summary of Civics.

\section{Observation results of Trial from the observer (Real Teaching)}

The results of learning observations in Lesson study activities are described as follows: (1) all students have actually learned about the learning that has been implemented. This is evidenced by: (a) students can interact and answer all questions from the teachers, (b) students are free to argue about the provided material, (2) there are some students who can not follow the learning activities, and some students do not express their opinions, (3) students who do not express their opinions because they are less concentration for the props are shown not too big, and there are shy studnets who less communicate with their friend.(4) the efforts that teachers can make to encourage passive students are: (a) the teacher should be thoroughly attentive so that the passive students feel cared for, (b) teachers encourage students by the humorous tricks to make the students not sleepy again, (c) sing together, (d) the teacher can point the studnet in the middle of explaination to delivery of information, (e) teacher should more give questions to the students. (5) 
valuable lessons learned from learning are: (a) learning is important facilitator and motivator, (b) it is good learning because students can do something directly (tasting traditional food), (c) the presence of ice breaking like Penguin dance can increase the spirit of students in the learning process, and (d) it needs to be gentle to students, (e) student motivation increases in learning through video display, (f) friendly teachers are love by the students.

\section{Discussions}

Lesson Plan (LP) produced through this lesson study agrees with Brady's appeal in Kovalik (1994) which stated that the primary goal of the school should help students understand their world. Besides, the material in Intergrated Thematic LP is not manifested in the form of subject matter separately, this is in accordance with the theory stated Rofi 'uddin (1996) and the theory of Skemp (1971) which mentioned that knowledge must be built by students themselves based on experience/knowledge that always owned before.

The approach of learning Integrated Thematic learning uses Scientific approach according to the opinion of Widayati (2014) that is by observing, asking, trying, reasoning and communicating. In addition to the Integreted Thematic LP produced through the lesson study in this reserach and the implementation of its learning is a form of the implementation of curriculum 2013 which is in accordance with the theory of Sunarti and Rhamawati (2014) that stated that the Scientific Approach in learning as intended includes observing, questioning, reasoning, trying and networking for all subjects.

In sake of the trained teachers of grade 3 in making integrated thematic LP and producing VCD of learning integrated thematic implementation of lesson through lesson study add insight that can help the teachers in carrying out their duties in implementing curriculum 2013, it is appropriate with the meaning of lesson study expressed by Garfield in Ibrohim (2012) mentioned that a systematic process used by Japanese teachers to test the effectiveness of its teaching in order to improve its learning outcomes. Hopefully for future research (fiscal year 2016/2017) will carry out on a wide scale researh (20 SD), since in 2015/2016, this research limited the scale (12 SD).

\section{Conclusions}

Based on the results of this research can be concluded as below: (1) the results of questionnaires answers of 3rd grade teachers about the knowledge of lesson study is almost $100 \%$ wrong, in other words the teacher's knowledge about lesson study is little; (2) to increase teachers' insight about lesson study, it is required a training which more focuses on Lesson Study materials; (3) making thematic learning tools for the teachers of grade 3 in the form of LP that is suitable curriculum 2013 needs to be socialized in a broader scale through lesson study; (4) VCD production results need to be disseminated (played) in elementary schools located in Malang City as an example of integrated thematic learning implememntation according to curriculum 2013.

Based on conclusions mentioned above, it is recommended to conduct similar research but in a broader scale. The participants of Lesson Study should be added, for example in this research followed by 12 teachers (limited scale) the next research might be followed by 20 teachers (large scale), so that the LP according to curriculum 2013 and the implementation of learning which made in VCD will achieve better quality. 
Journal of Social Sciences (COES\&RJ-JSS), 6(4), pp. 902-911

\section{References}

Ibrohim, 2012. Panduan Pelaksanaan Lesson Study di KKG. Malang : Kerjasama PT Pertamina dan UM.

Kovalik, Susan, 1994. ITI : The Model Integrated Tematic Instruction. Suite : Susan Kovalik dan Associates.

Kurniasih dan Sani. 2014. Sukses Mengimplementasikan Kurikulum 2013. Jakarta : Kata Pena.

Rofi'uddin, Ahmad. 1996. Penilaian Pembelajaran Bahasa Indonesia di Sekolah Dasar. Malang : PPS IKIP Malang.

Skemp, Richard R. 1971. The Psychology of Learning Mathematics. Great Britain : Hazell Watson dan Viney Ltd.

Ulfatin, Nurul. 2012. Metode Penelitian Kuantitatif di Bidang Pendidikan, Teori dan Aplikasinya. Malang : Media Nusa Creative.

Widayati.2014. Pendekatan Scientific. Malang : KSDP UM. 